\title{
Communication
}

\section{Benzalaniline from nitrobenzene and benzaldehyde catalyzed efficiently by an atomically precise palladium nanocluster}

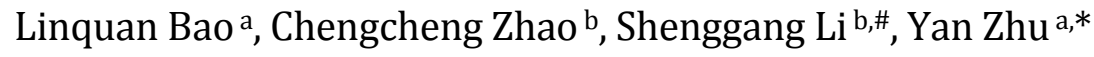 \\ a Key Laboratory of Mesoscopic Chemistry, MOE, School of Chemistry and Chemical Engineering, Nanjing University, Nanjing 210093, Jiangsu, China \\ b Shanghai Advanced Research Institute, Chinese Academy of Sciences, Shanghai 201210, China
}

\section{A R T I C L E I N F}

\section{Article history:}

Received 18 June 2019

Accepted 16 July 2019

Published 5 October 2019

\section{Keywords:}

Nanoclusters

Palladium

Reductive amidation

Selectivity

Activity

\begin{abstract}
A B S T R A C T
Nanoclusters with a precise number of atoms may exhibit unique and often unexpected catalytic properties. Here, we report an atomically precise $\mathrm{Pd}_{3}$ nanocluster as an efficient catalyst, whose catalytic performance differs remarkably from typical Pd nanoparticle catalysts, with excellent reactivity and selectivity in the one-pot synthesis of benzalaniline from nitrobenzene and benzaldehyde. We anticipate that our work will serve as a starting point for the catalytic applications of these tiny atomically precise nanoclusters in green chemistry for the one-pot syntheses of fine chemicals.
\end{abstract}

(C) 2019, Dalian Institute of Chemical Physics, Chinese Academy of Sciences. Published by Elsevier B.V. All rights reserved.
Metal nanoparticles are the active catalysts for the majority of current chemical processes [1,2]. However, conventional nanoparticle catalysts have several major issues, particularly the inherent size polydispersity, and the difficulty in precisely controlling the structure at the atomic level [3]. These major limitations preclude fundamental investigations on the precise structure-activity relationships, e.g., it is usually impossible to unambiguously identify the catalytically active species in nanoparticle catalysis [4-6]. The majority of current studies offer an ensemble average of the catalytic performance due to the structural polydispersity and heterogeneity of conventional nanoparticle catalysts. Although significant efforts have been invested in preparing well-defined nanoparticles as model catalysts, fundamental catalysis research still lags behind [7]. Therefore, generalizing the synthesis of atomically precise metal nanoclusters and using them as well-defined catalysts are of paramount importance. Atomically monodisperse nanoclusters are composed of an exact number of metal atoms, and thus differ from the respective metal nanoparticles [8-11]. More importantly, based on their atom packing structures and unique electronic properties, these nanoclusters permit the precise correlation of particle structure and catalytic properties, which may help the identification of active sites on the metal nanoparticle catalysts [12]. This is the long-standing goal of catalysis research.

Amidation reaction is an important route for producing pharmaceuticals, agrochemicals, dyes, and fine chemicals $[13,14]$. Significant efforts have been invested in the efficient synthesis of imines from secondary amines under mild conditions favorable for practical applications [15-17]. However, the one-pot synthesis of benzalaniline involves the condensation of a carbonyl compound and an amine, and is therefore, difficult

\footnotetext{
* Corresponding author. E-mail: zhuyan@nju.edu.cn

\# Corresponding author. E-mail: lisg@sari.ac.cn

We acknowledge financial supports from National Natural Science Foundation of China $(21773109,91845104)$.

DOI: S1872-2067(19)63423-6 | http://www.sciencedirect.com/science/journal/18722067 | Chin. J. Catal., Vol. 40, No. 10, October 2019
} 
to realize due to the exceedingly active nature of carbonyl compounds [18]. It has been shown that the formation of C-N bonds can be accomplished in the presence of $\mathrm{Pd} / \mathrm{C}$, Ir complex, or FeII/EDTA complex [19] through transfer hydrogenation or by utilizing a reducing agent; however, these methods are incompatible with imines containing $\mathrm{C}=\mathrm{N}$ bonds.

In this study, we utilize a three-Pd-atom nanocluster protected by ligands to catalyze the one-pot synthesis of benzalaniline from nitrobenzene and benzaldehyde, and our catalyst exhibited efficient conversion and selectivity toward the partially hydrogenated product (benzalaniline). For comparison, conventional Pd nanoparticles were also synthesized and applied to the same reaction, and they afforded a completely hydrogenated product (benzylaniline). Our studies promote the exploration of well-defined nanoclusters as highly efficient catalysts for the synthesis of fine chemicals.

The composition of the Pd nanocluster was determined by matrix-assisted laser desorption ionization mass spectrometry (MALDI-MS) (Fig. 1(a)), which confirmed that the formula of the nanocluster is $\mathrm{Pd}_{3} \mathrm{Cl}\left(\mathrm{PPh}_{2}\right)_{2}\left(\mathrm{PPh}_{3}\right)_{3}$ (abbreviated as $\mathrm{Pd}_{3}$, hereinafter), which is consistent with the peak located at 1511 Da (note that the peaks at 984 and $1249 \mathrm{~m} / \mathrm{z}$, marked by the asterisks, are fragments resulting from MALDI instead of impurities, and the peaks might be assigned to $\mathrm{Pd}_{3} \mathrm{Cl}\left(\mathrm{PPh}_{2}\right)_{2}\left(\mathrm{PPh}_{3}\right)_{2}$ and $\mathrm{Pd}_{3} \mathrm{Cl}\left(\mathrm{PPh}_{2}\right)_{2}\left(\mathrm{PPh}_{3}\right)$, respectively). The atomic structure of the $\mathrm{Pd}_{3}$ nanocluster can be viewed as a triangle, as shown in Fig. 1(b), capped by one $\mathrm{Cl}$, two $\mathrm{PPh}_{2}$, and three $\mathrm{PPh}_{3}$ ligands. The non-metallic nature of the $\mathrm{Pd}_{3}$ nanocluster is manifested in

a

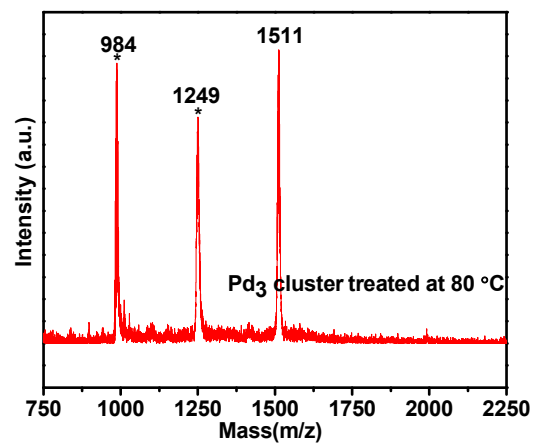

C

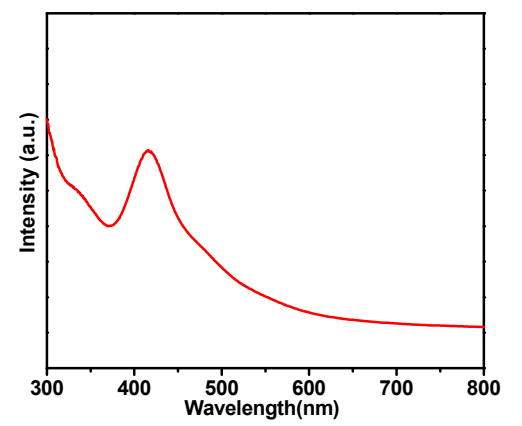

its optical spectrum (Fig. 1(c)), which exhibits multiple absorption bands centered at 340, 418, and $485 \mathrm{~nm}$ (reminiscent of quantum dot behavior). X-ray photoelectron spectroscopy (XPS) analysis shows that the apparent binding energies of the $\mathrm{Pd} 3 d$ electrons in the $\mathrm{Pd}_{3}$ nanocluster are blue-shifted, compared to the case with the bulk Pd electrons (Fig. 1(d)). The blue shift in the binding energy is typical for very small particles [20]. Note that the peak at $336.9 \mathrm{eV}$ is assigned to $\mathrm{Pd}^{2+}$ and the peak at $336.4 \mathrm{eV}$ to $\mathrm{Pd}^{0}$, indicating that the average charge carried by the Pd atoms in the nanocluster is relatively close to zero. These data revealed the unique structural and electronic properties of the $\mathrm{Pd}_{3}$ nanocluster, which differed remarkably from those of the corresponding Pd nanoparticles.

Upon deposition of the $\mathrm{Pd}_{3}$ nanoclusters onto the oxide supports $\left(\gamma-\mathrm{Al}_{2} \mathrm{O}_{3}, \mathrm{SiO}_{2}, \mathrm{MgO}\right.$, and $\left.\mathrm{TiO}_{2}\right)$, transmission electron microscopy (TEM) images clearly demonstrated the average size of the $\mathrm{Pd}_{3}$ clusters, i.e., about $2 \mathrm{~nm}$, supported on $\gamma-\mathrm{Al}_{2} \mathrm{O}_{3}$. For comparison, Pd nanoparticles supported on these oxides were also prepared, and the average size was around 2-3 nm (Fig. S1). High-resolution TEM studies of the Pd nanoparticles indicated that the lattice spacing of $0.195 \mathrm{~nm}$ can be assigned to the $\{200\}$ lattice fringes (Fig. S1).

The one-pot synthesis of benzalaniline from nitrobenzene and benzaldehyde was selected as a model reaction to distinguish the catalytic performance of the $\mathrm{Pd}_{3}$ nanocluster from that of Pd nanoparticles. As listed in Table 1, the catalytic activity of $\mathrm{Pd}_{3}$ is superior to that of Pd nanoparticles for this reaction. With the free $\mathrm{Pd}_{3}$ nanocluster as the catalyst, an excellent

b

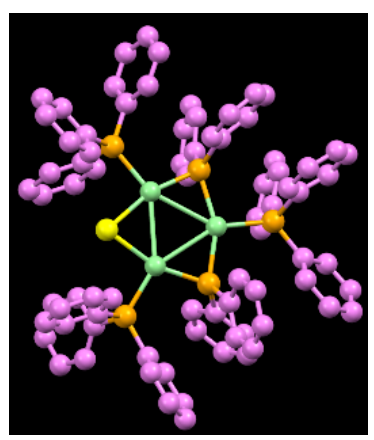

d

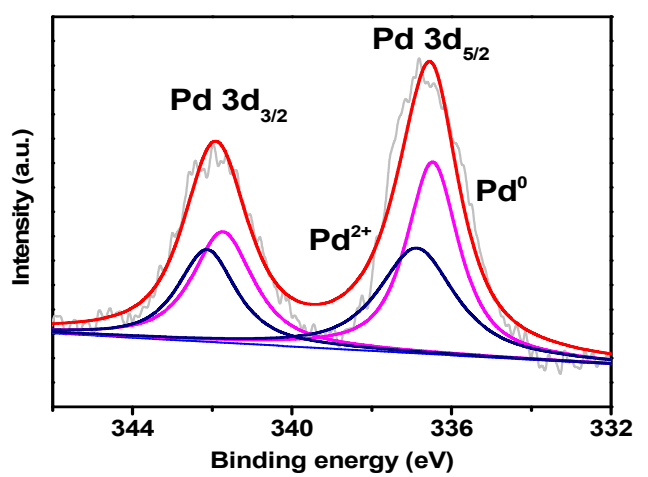

Fig. 1. MALDI-MS spectrum (a) and atomic structure (b) of the $\mathrm{Pd}_{3} \mathrm{Cl}\left(\mathrm{PPh}_{2}\right)_{2}\left(\mathrm{PPh}_{3}\right)_{3}$ nanocluster. Color labels: green, $\mathrm{Pd}$; pink, $\mathrm{C}$; yellow, $\mathrm{Cl}$; orange, $\mathrm{P}$. $\mathrm{H}$ atoms are omitted for clarity. UV-vis (c) and Pd $3 d$ XPS (d) profiles of the $\mathrm{Pd}_{3}$ nanoclusters. 
Table 1

Catalytic performance of the $\mathrm{Pd}_{3}$ nanoclusters and $\mathrm{Pd}$ nanoparticles for the benzalaniline synthesis of nitrobenzene and benzaldehyde. ${ }^{\mathrm{a}}$

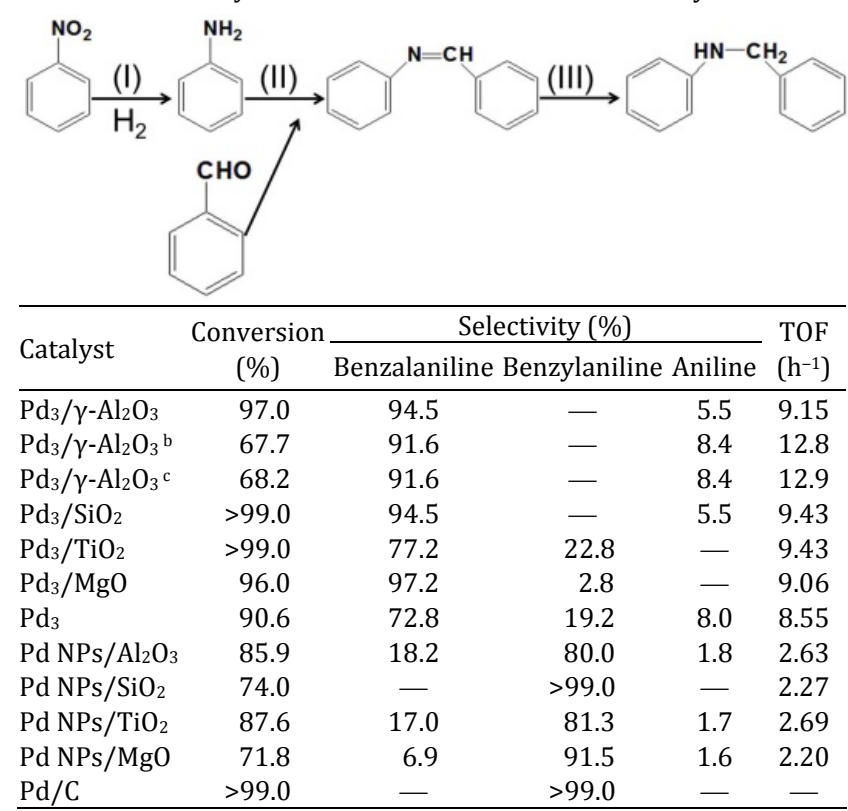

a Reaction conditions: $50 \mathrm{mg}$ of catalysts (1 wt\% Pd), $1.0 \mathrm{mmol}$ benzaldehyde, $1.2 \mathrm{mmol}$ nitrobenzene, $15 \mathrm{~mL}$ of methanol, $80{ }^{\circ} \mathrm{C}, 2 \mathrm{MPa} \mathrm{H}_{2}, 20$ h. NPs: nanoparticles. The conversion was calculated based on nitrobenzene.

b The reaction time was $10 \mathrm{~h}$.

cAfter a 10 -h reaction, the catalyst was removed by centrifugation, and the reaction continued for another $10 \mathrm{~h}$.

nitrobenzene conversion of $90.6 \%$ could already be achieved. The $\mathrm{Pd}_{3}$ nanoclusters supported by oxides displayed even better catalytic activity than that of Pd nanoparticles with a conversion exceeding $96.0 \%$ under the same reaction condition, regardless of the support being used, which had no inherent catalytic activity. The supported $\mathrm{Pd}_{3}$ nanocluster showed a higher conversion than that of supported Pd nanoparticles by 10-25\%. More importantly, the $\mathrm{Pd}_{3}$ nanoclusters and Pd nanoparticles exhibited distinct product selectivity, with the $\mathrm{Pd}_{3}$ nanocluster favoring the partially hydrogenated product (benzalaniline), and the Pd nanoparticles favoring the completely hydrogenated product (benzylaniline). The highest selectivity towards benzalaniline was obtained with the $\mathrm{Pd}_{3}$ nanoclusters supported by $\mathrm{MgO}$. In addition, the commercial $\mathrm{Pd} / \mathrm{C}$ catalyst afforded very high conversion of nitrobenzene, but a very low selectivity towards benzalaniline.

To show the stability of the $\mathrm{Pd}_{3}$ catalyst, the cycle performance of $\mathrm{Pd}_{3} / \gamma-\mathrm{Al}_{2} \mathrm{O}_{3}$ was tested using recycled catalysts under the same reaction conditions after simple centrifugation and washing with methanol. As illustrated in Fig. S2, no obvious decrease in the activity was observed, indicating the excellent reliability of this reaction system. To detect possible Pd leaching from the catalysts, inductively coupled plasma (ICP) spectroscopy was employed to measure the Pd species in the reaction solution, and no Pd species was detected. Furthermore, we conducted a comparison experiment: the reaction proceeded for $10 \mathrm{~h}$, after which the catalyst was isolated. Subsequently, the reaction continued without the Pd catalyst for another $10 \mathrm{~h}$.
Consequently, the conversion of nitrobenzene in the reaction system without the $\mathrm{Pd}_{3}$ catalyst did not increase compared to that in the first $10 \mathrm{~h}$ of reaction with the $\mathrm{Pd}_{3}$ catalyst (Table 1), which further indicated that the leaching phenomenon of $\mathrm{Pd}$ was negligible. The $\mathrm{Pd}_{3}$ nanoclusters were very stable during the reaction, which was confirmed by the UV-vis spectroscopic fingerprints of the fresh and used catalysts, and no obvious spectral change was observed (Fig. S3).

To elucidate the mechanism for the distinct catalytic performances of the $\mathrm{Pd}_{3}$ nanoclusters and Pd nanoparticles, $\mathrm{H}-\mathrm{D}$ exchange was carried out to explain how the atomic arrangement of Pd catalysts controlled the selective hydrogenation in the amidation reaction. Fig. 2 presents the significant $\mathrm{H}-\mathrm{D}$ evolutions with the increasing temperatures of $\gamma-\mathrm{Al}_{2} \mathrm{O}_{3}$, $\mathrm{Pd}_{3} / \gamma-\mathrm{Al}_{2} \mathrm{O}_{3}$, and $\mathrm{Pd} \mathrm{NPs} / \gamma-\mathrm{Al}_{2} \mathrm{O}_{3}$. In these $\mathrm{H}-\mathrm{D}$ exchange experiments, four kinds of surface $\mathrm{H}$ species related to the three samples could be identified. The H-D evolution peak, $\alpha$, observed at $303{ }^{\circ} \mathrm{C}$, was mainly due to the hydroxyl (HO-Al). For $\mathrm{Pd}_{3} / \gamma-\mathrm{Al}_{2} \mathrm{O}_{3}$, the new peak, $\beta$, located at $133{ }^{\circ} \mathrm{C}$ was assigned to the specific $\mathrm{H}$ species connected to the $\mathrm{Pd}_{3}$ clusters, since the initial peak belonging to $\mathrm{HO}-\mathrm{Al}$ is quite distant from it. For the $\mathrm{Pd}$ nanoparticles supported on $\gamma-\mathrm{Al}_{2} \mathrm{O}_{3}$, there are two evolution peaks located at 168 and $264^{\circ} \mathrm{C}$ : the first peak, denoted by $\gamma$, is assigned to the chemisorbed $\mathrm{H}$ on the Pd nanoparticles; the second, denoted by $\delta$, originates from $\mathrm{HO}-\mathrm{Al}$, which shifts to lower temperature due to the dissociation of its $\mathrm{H}$ catalyzed by the Pd contents [21,22]. Thus, compared to that of $\gamma-\mathrm{Al}_{2} \mathrm{O}_{3}$, the abilities of $\mathrm{Pd}_{3} / \gamma-\mathrm{Al}_{2} \mathrm{O}_{3}$ and $\mathrm{Pd} \mathrm{NPs} / \gamma-\mathrm{Al}_{2} \mathrm{O}_{3}$ to dissociate $\mathrm{H}$ are both enhanced, although to different levels, with $\mathrm{Pd}$ $\mathrm{NPs} / \gamma-\mathrm{Al}_{2} \mathrm{O}_{3}$ reaching $\mathrm{H}-\mathrm{D}$ equilibrium at a temperature higher than that of $\mathrm{Pd}_{3} / \gamma-\mathrm{Al}_{2} \mathrm{O}_{3}$ by $35^{\circ} \mathrm{C}$. The $\mathrm{H}-\mathrm{D}$ exchange results show that $\mathrm{Pd}_{3} / \gamma-\mathrm{Al}_{2} \mathrm{O}_{3}$ is more active for the hydrogenation during the one-pot synthesis of benzalaniline from nitrobenzene and benzaldehyde

Temperature-programmed desorption (TPD) is usually adopted to measure the adsorption strength and capacity of the adsorbents onto the catalysts. The TPD spectra of $\mathrm{H}$ and benzalaniline on the $\mathrm{Pd}_{3}$ nanoclusters and Pd NPs are illustrated in

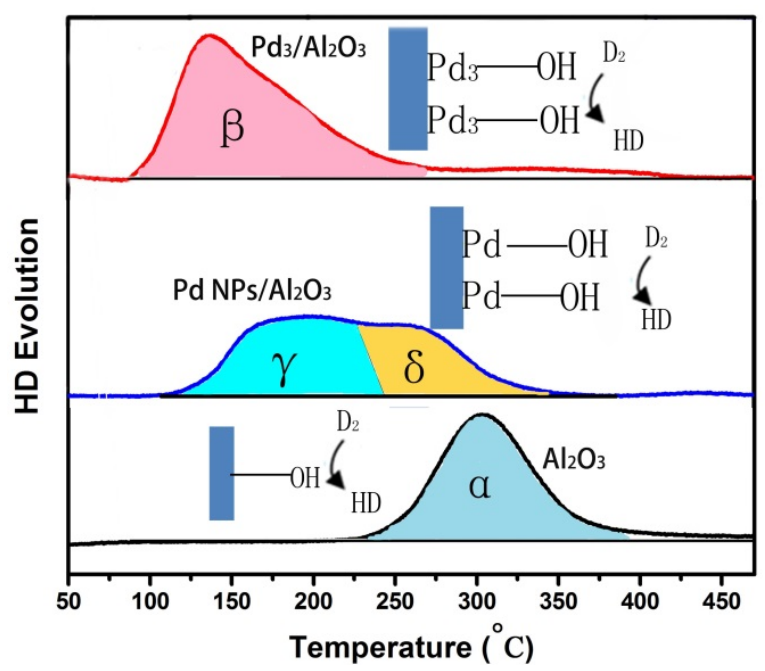

Fig. 2. $\mathrm{H}-\mathrm{D}$ exchange profiles of $\mathrm{Pd}_{3} / \gamma-\mathrm{Al}_{2} \mathrm{O}_{3}, \mathrm{Pd} \mathrm{NPs} / \gamma-\mathrm{Al}_{2} \mathrm{O}_{3}$, and $\gamma-\mathrm{Al}_{2} \mathrm{O}_{3}$. 

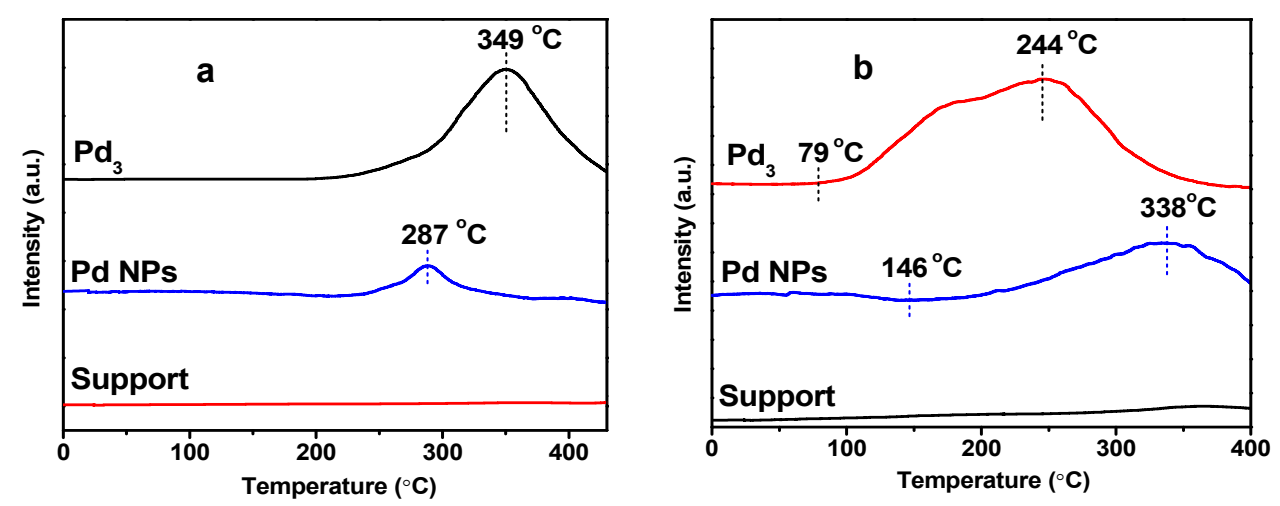

Fig. 3. TPD profiles of $\mathrm{H}_{2}$ (a) and benzalaniline (b) for different samples.

Fig. 3. As shown in Fig. 3(a), no $\mathrm{H}$ was adsorbed on the bare support and $\mathrm{H}$ was only adsorbed on the Pd sites. The peak at $349^{\circ} \mathrm{C}$ for the $\mathrm{Pd}_{3}$ nanocluster was assigned to the chemisorption of $\mathrm{H}$, whereas the peak indicative of the hydrogenation desorption for Pd NPs was located at $287^{\circ} \mathrm{C}$. Although the Pd NPs was found to have a lower hydrogen desorption temperature than that of the $\mathrm{Pd}_{3}$ catalyst, the $\mathrm{Pd}_{3}$ catalyst exhibited a relatively larger peak area than that of the Pd NPs. The ratio of the desorption peak areas for these two samples was estimated to be $\sim 2.9: 1$. The amount of $\mathrm{H}$ desorbed by TPD was consistent with the change in the amount of $\mathrm{H}$ measured by chemisorption, which reflected the change in the dispersion of the active components in the catalyst $[23,24]$. These phenomena indicated that the $\mathrm{H}$ chemisorption capacity of the $\mathrm{Pd}_{3}$ catalyst was greater than that of the Pd NPs, which is consistent with the higher hydrogenation activity of the $\mathrm{Pd}_{3}$ catalyst.

Moreover, there were significant differences from the benzalaniline-TPD results of the $\mathrm{Pd}_{3}$ and Pd NPs catalysts. As shown in Fig. 3(b), the desorption of benzalaniline over $\mathrm{Pd}_{3}$ started at $79^{\circ} \mathrm{C}$ and reached maximum speed at $244{ }^{\circ} \mathrm{C}$, while the initial desorption of benzalaniline over Pd NPs occurred at around $146{ }^{\circ} \mathrm{C}$; the fastest desorption occurred at $338^{\circ} \mathrm{C}$. The adsorption capacities of benzalaniline deduced from the peak areas suggested that the interaction of benzalaniline with $\mathrm{Pd}_{3}$ was much weaker than that with Pd NPs, and thus relatively high selectivity for benzalaniline was achieved by $\mathrm{Pd}_{3}$. The in- triguing point is that the asymmetric shape of the peaks is in conjunction with the first order kinetics [25], implying that the adsorption behavior is non-dissociative. In conclusion, the results demonstrate that benzalaniline was easily formed in the $\mathrm{Pd}_{3}$ system rather than in the Pd NPs.

Density functional theory (DFT) calculations were performed using the $\mathrm{Pd}_{3}$ cluster and the $\mathrm{Pd}(100)$ surface as models of the $\mathrm{Pd}_{3}$ nanocluster and $\mathrm{Pd}$ nanoparticle catalysts, respectively, to elucidate the catalytic mechanism and the reason behind the different product selectivities. Fig. 4(a) presents the potential energy surface (PES) for the formation of benzalaniline $(\mathrm{PhN}=\mathrm{CHPh})$ from the reaction of aniline $\left(\mathrm{PhNH}_{2}\right)$ and benzaldehyde $(\mathrm{PhCH}=0)$ catalyzed by the $\mathrm{Pd}_{3}$ cluster. Although nitrobenzene $\left(\mathrm{PhNO}_{2}\right)$ was used as the $\mathrm{N}$ source, it was expected to be readily reduced to aniline by hydrogenation, and the latter was actually involved in the reductive coupling reaction with benzaldehyde. As shown in the enlarged image of the $\mathrm{Pd}_{3}$ cluster (Figs. 4(a) and S5, A-1), the $\mathrm{Pd}_{3}$ core is capped by three terminal $\mathrm{PPh}_{3}$ neutral ligands below the plane, two bridge $\mathrm{PPh}_{2}$, and one bridge $\mathrm{Cl}$ anionic ligand above the plane; the adsorption of the reactants will displace the relatively small $\mathrm{Cl}$ ligand. When the $\mathrm{Cl}$ anion is displaced by the $\mathrm{O}$ from $\mathrm{PhCH}=0$ (A-2), it still interacts with the rest of the cluster by electrostatic force, and this step is predicted to be quite exothermic $(-2.24$ $\mathrm{eV}$ ), suggesting that the adsorption of $\mathrm{PhCH}=\mathrm{O}$ is very favorable. This is followed by the transfer of $\mathrm{H}$ from $\mathrm{PhNH}_{2}$ to the $\mathrm{O}$
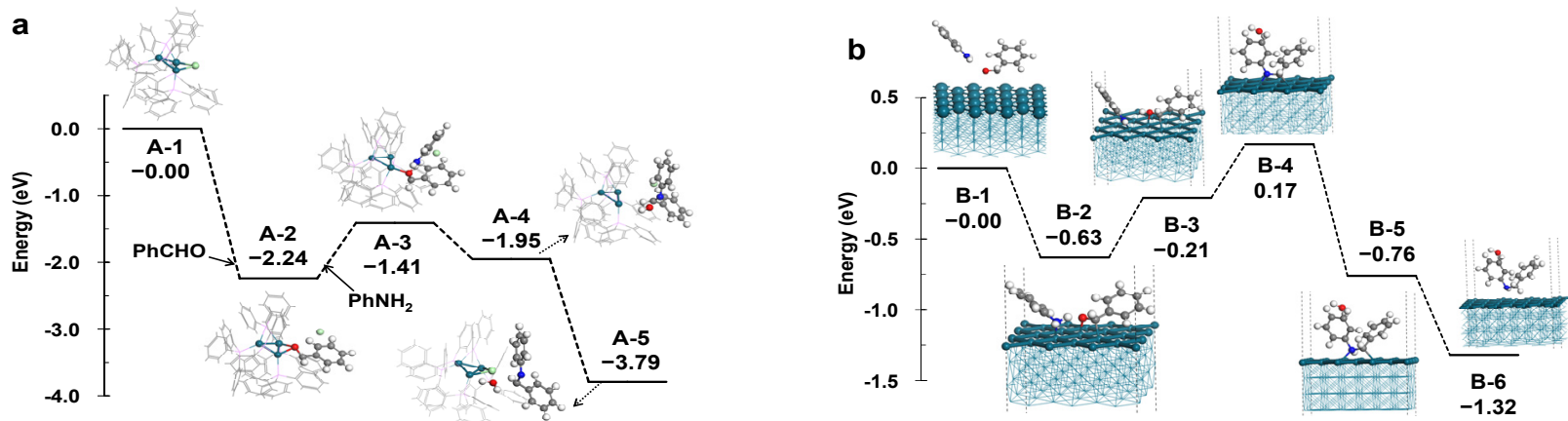

Fig. 4. Potential energy surfaces for the reaction between aniline $\left(\mathrm{PhNH}_{2}\right)$ and benzaldehyde $(\mathrm{PhCH}=0)$ over the $\mathrm{Pd} \mathrm{d}_{3}$ cluster $(\mathrm{a})$ and the $\mathrm{Pd}(100)$ surface as catalyst models (b) for the supported $\mathrm{Pd}_{3}$ and $\mathrm{Pd}$ nanoparticle catalysts. Only atoms relevant to the reaction are displayed with $\mathrm{C}, \mathrm{H}, \mathrm{N}$, and $\mathrm{Pd}$ atoms shown in black, white, blue, and light green, respectively. Enlarged images are given in Figs. S4-S6. 
atom on the adsorbed $\mathrm{PhCH}=\mathrm{O}(\mathrm{A}-3)$, which is modestly endothermic $(0.83 \mathrm{eV})$. Subsequently, $\mathrm{PhN}=\mathrm{CHPh}$ is formed by further $\mathrm{H}$ transfer from $\mathrm{N}$ to $\mathrm{O}$, accompanied by the formation of $\mathrm{H}_{2} \mathrm{O}(\mathrm{A}-4)$, which is exothermic $(-0.54 \mathrm{eV})$. The interaction of $\mathrm{PhN}=\mathrm{CHPh}$ with the $\mathrm{Pd}_{3}$ core is found to be much weaker than that with the $\mathrm{Cl}$ anion; therefore, the regeneration of the $\mathrm{Pd}_{3}$ catalyst $(\mathrm{A}-5)$ is also exothermic $(-1.84 \mathrm{eV})$. The selective formation of $\mathrm{PhN}=\mathrm{CHPh}$ is partly due to its weak interaction with the $\mathrm{Pd}_{3}$ cluster; thus, its further hydrogenation is unfavorable.

For the one-pot synthesis of benzalaniline from $\mathrm{PhNO}_{2}$ and $\mathrm{PhCH}=0$ catalyzed by the $\mathrm{Pd}(100)$ surface, we focused our calculations on the hydrogenative coupling between $\mathrm{PhNH}_{2}$ and $\mathrm{PhCH}=0$. Although the $\mathrm{Pd}(100)$ surface can simultaneously adsorb both reactants, $\mathrm{PhNH}_{2}$ through $\mathrm{N}$, and $\mathrm{PhCH}=\mathrm{O}$ through $\mathrm{C}$ and $\mathrm{O}$ (Figs. 4(b) and S6, B-2), the adsorption is not very strong, as the combined adsorption energy is only $-0.63 \mathrm{eV}$. Therefore, two $\mathrm{H}$ transfer steps (B-3 and B-4) occur from $\mathrm{N}$ to $\mathrm{O}$ to form $\mathrm{H}_{2} \mathrm{O}$ and $\mathrm{PhN}=\mathrm{CHPh}$, both of which are slightly endothermic ( 0.42 and $0.38 \mathrm{eV}$, respectively). Unlike the case of the $\mathrm{Pd}_{3}$ cluster, where the adsorption of $\mathrm{PhN}=\mathrm{CHPh}$ is weaker than that of the $\mathrm{Cl}$ anion, here, $\mathrm{PhN}=\mathrm{CHPh}$ is quite strongly adsorbed on the $\mathrm{Pd}(100)$ surface via both $\mathrm{N}$ and $\mathrm{C}$ atoms. Due to the presence of adsorbed $\mathrm{H}$ on the $\mathrm{Pd}(100)$ surface, $\mathrm{PhN}=\mathrm{CHPh}$ can further be hydrogenated to form benzylaniline $\left(\mathrm{PhNHCH}_{2} \mathrm{Ph}\right)$ also in two steps (B-5 and B-6), both of which are exothermic $(-0.93$ and $-0.56 \mathrm{eV})$; therefore, the formation of the completely hydrogenated product is more favorable over the Pd nanoparticle catalyst. Thus, the difference in the selectivities between the $\mathrm{Pd}_{3}$ cluster and $\mathrm{Pd}$ nanoparticle catalysts is largely due to the presence of protective ligands in the former, which inhibit the complete hydrogenation of $\mathrm{PhN}=\mathrm{CHPh}$.

In summary, we discovered an efficient and easily recyclable $\mathrm{Pd}_{3}$ nanocluster catalyst for the one-pot synthesis of benzalaniline from nitrobenzene and benzaldehyde, which exhibited very high activity and selectivity toward the partially hydrogenated product, in sharp contrast to the catalytic performance of typical Pd nanoparticles that afforded the completely hydrogenated product. The different behaviors in the adsorption and reaction of the reactants of the two catalysts are found to be responsible for their distinct catalytic behaviors based on both catalyst characterizations and theoretical calculations. The atomically precise metal nanoclusters give way to a new type of metal catalyst with high efficiency for certain industrially important chemical processes and highlight the importance of pursuing atomic-precise metal nanoclusters for catalysis science and technology.

\section{Acknowledgments}

We acknowledge financial supports from National Natural Science Foundation of China $(21773109,91845104)$.

\section{References}

[1] A. Alshammari, V. N. Kalevaru, A. Martin, In: Green Nanotechnology-Overview and Further Prospects, M. Larramendy, eds., Intechopen, Rijeka, 2016, 1-34.

[2] S. Wang, B. Zeng, C. Li, Chin. J. Catal., 2018, 39, 1219-1227.

[3] Y. Xia, T. D. Nguyen, M. Yang, B. Lee, A. Santos, P. Podsiadlo, Z. Tang, S. C. Glotzer, N. A. Kotov, Nat. Nanotechnol., 2011, 6, 580-587.

[4] P. Wang, S. Xu, F. Chen, H. Yu, Chin. J. Catal, 2019, 40, 343-351.

[5] D. Astruc, F. Lu, J. R. Aranzaes, Angew. Chem. Int. Ed., 2005, 44, 7852-7872.

[6] Y.-G. Wang, D. Mei, V.-A. Glezakou, J. Li, R. Rousseau, Nat. Commun., 2015, 6, 6511-6519.

[7] M. Haruta, M. Daté, Appl. Catal. A, 2001, 222, 427-437.

[8] X. Kang, H. Chong, M. Zhu, Nanoscale, 2018, 10, 10758- 10834.

[9] F. Fu, J. Xiang, H. Cheng, L. Cheng, H. Chong, S. Wang, P. Li, S.Wei, M. Zhu, Y. Li, ACS Catal., 2017, 7, 1860-1867.

[10] Y. Tan, H. Liu, X. Y. Liu, A. Wang, C. Liu, T. Zhang, Chin. J. Catal., 2018, 39, 929-936.

[11] Y. Zhu, H. Qian, B. A. Drake, R. Jin, Angew. Chem. Int. Ed., 2010, 49, 1295-1298.

[12] G. Li, R. Jin, Acc. Chem. Res., 2013, 46, 1749-1758.

[13] J. Ward, R. Wohlgemuth, Curr. Org. Chem., 2010, 14, 1914-1927.

[14] J. Matsuo, Y. Tanaki, H. Ishibashi, Org. Lett., 2006, 8, 4371-4374.

[15] R. Yamaguchi, C. Ikeda, Y. Takahashi, K.-I. Fujita, J. Am.Chem. Soc., 2009, 131, 8410-8412.

[16] A. Nishinaga, S. Yamaza ki, T. Matsuura, Tetrahedron Lett., 1988,

\section{Graphical Abstract}

Chin. J. Catal., 2019, 40: 1499-1504 doi: S1872-2067(19)63423-6

\section{Benzalaniline from nitrobenzene and benzaldehyde catalyzed} efficiently by an atomically precise palladium nanocluster

Linquan Bao, Chengcheng Zhao, Shenggang Li*, Yan Zhu*

Nanjing University; Shanghai Advanced Research Institute, Chinese Academy of Sciences

Three-atom-Pd nanocluster protected by $\mathrm{PPh}_{2}$ and $\mathrm{PPh}_{3}$ ligands was found to exhibit unique conversion and selectivity toward the partially hydrogenated product in the catalysis of the reductive amidation of nitrobenzene and benzaldehyde.

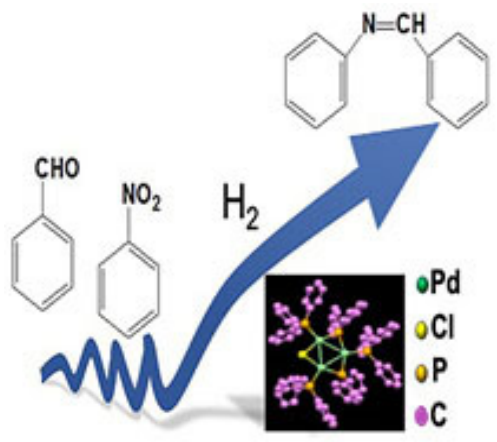


29, 4115-4118

[17] K. Yamaguchi, N. Mizuno, Angew. Chem. Int. Ed., 2003, 42, 1479-1483.

[18] A. Grirrane, A. Corma, H. Garcia, J. Catal., 2009, 264, 138-144.

[19] J. Deng, L.-P. Mo, F.-Y. Zhao, L.-L. Hou, L. Yang, Z.-H. Zhang, Green Chem., 2011, 13, 2576-2584.

[20] B. Delley, D. E. Ellis, A. J. Freeman, E. J. Baerends, D. Post, Phys. Rev. $B, 1983,27,2132-2144$.

[21] V. Almasan, T. Gaeumann, M. Lazar, P. Marginean, N. Aldea, In Stud.
Surf. Sci. Catal., 1997, 5. 547-552.

[22] T. Fu, M. Wang, W. Cai, Y. Cui, F. Gao, L. Peng, W. Chen, W. Ding, ACS Catal., 2014, 4, 2536-2543.

[23] I. Witońska, S. Karski, M. Frajtak, N. Krawczyk, A. Królak, React. Kinet. Catal. Lett., 2008, 93, 241-248.

[24] R. S. Smith, R. A. May, B. D. Kay, J. Phys. Chem.B, 2015, 120, 1979-1987.

[25] D. Li, R. Li, M. Lu, X. Lin, Y. Zhan, L. Jiang, Appl. Catal. B, 2017, 200, 566-577.

\title{
原子精度的钯原子簇催化硝基苯和苯甲醛反应制备苯甲酰胺
}

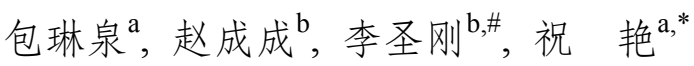 \\ a南京大学化学化工学院, 介观化学教育部重点实验室, 江苏南京210093 \\ b 中国科学院上海高等研究院, 低碳转化科学与工程中心, 上海201210
}

\begin{abstract}
摘要: 金属纳米颗粒催化剂在现代化学工业及相关催化领域研究中具有至关重要的地位, 然而常规纳米颗粒催化剂的一 个主要问题是尺寸多分散, 导致难以在原子水平上精确控制其活性物种结构, 从而阻碍在原子水平上建立精准的催化剂结 构与性能之间的对应关系. 因此, 人们极需构筑和研究新型具有原子精度的催化材料. 具有确定原子数目和精确结构的金 属原子簇往往呈现出类似于分子的行为和特殊的电子结构, 是一种介于均相与多相之间的结构精准的新型催化剂, 其催化 性能能够从原子水平上真正反映催化剂结构的影响, 提供催化作用本质的清晰信息, 对理解催化剂构效关系有重要意义, 可以解决常规催化剂所面临的一些难题.

本文报道了一种原子精度的 $\mathrm{Pd}_{3}$ 原子簇催化剂, 它在催化硝基苯和苯甲酫一锅法合成苄叉苯胺的反应中表现出比常规 的Pd纳米颗粒催化剂更优异的性能. $\mathrm{Pd}_{3}$ 原子簇催化剂可以高效地把硝基苯和苯甲醛转化为部分氢化产物(苄叉苯胺), 而 $\mathrm{Pd}$ 纳米颗粒催化此反应得到完全氢化的产物(芐基苯胺). 实验研究表明, 芐叉苯胺更容易从 $\mathrm{Pd}_{3}$ 原子簇催化剂表面脱附, 从 而抑制了芐叉苯胺的进一步加氢, 并提高了 $\mathrm{Pd}_{3}$ 原子簇催化剂对芐叉苯胺的选择性. 密度泛函计算进一步证实了芐叉苯胺 与 $\mathrm{Pd}_{3}$ 原子簇的相互作用比较弱, 芐叉苯胺更容易从 $\mathrm{Pd}_{3}$ 原子簇上脱附, 从而避免了其进一步加氢生成芐基苯胺, 这与 $\mathrm{Pd}$ 纳 米颗粒表面的催化性质截然不同.

综上所述, 我们报道了一种高效且易于回收的 $\mathrm{Pd}_{3}$ 原子簇催化剂, 并将其用于催化硝基苯和苯甲醛一锅法高效合成苯 甲酰苯胺. $\mathrm{Pd}_{3}$ 原子簇对此反应表现出了极高的反应活性并对部分氢化产物苄叉苯胺有极高的选择性, 而Pd纳米颗粒催化 剂则更加有利于生成完全加氢产物芐基苯胺. 基于实验和理论计算研究, 我们确认了两种催化剂上反应物的吸附和反应 的不同特性是导致其不同催化行为的主要原因.
\end{abstract}

关键词: 原子簇; 钯; 还原酰胺化; 选择性; 活性

收稿日期: 2019-06-18. 接受日期: 2019-07-16. 出版日期: 2019-10-05.

*通讯联系人. 电子信箱: zhuyan@nju.edu.cn

\#通讯联系人. 电子信箱: lisg@sari.ac.cn

基金来源：国家自然科学基金(21773109, 91845104).

本文的电子版全文由Elsevier出版社在ScienceDirect上出版(http://www.sciencedirect.com/science/journal/18722067). 